TITLE:

\title{
Suppression of allergic inflammation by the prostaglandin E receptor subtype EP3( Abstract_要旨 )
}

$\operatorname{AUTHOR}(S):$

Kunikata, Tomonori

\section{CITATION:}

Kunikata, Tomonori. Suppression of allergic inflammation by the prostaglandin E receptor subtype EP3. 京都大学, 2005, 博士(医学)

ISSUE DATE:

2005-07-25

URL:

http://hdl.handle.net/2433/144482

RIGHT: 


\begin{tabular}{|c|c|}
\hline 名 & 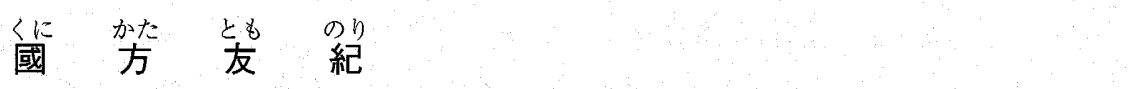 \\
\hline 学位(專攻分野) & 博 士 (医 学) \\
\hline 学位 記番 号 & 医 博 第 2903 号 \\
\hline 学位授与の日付 & 平成 17 年 7 月 25 日 \\
\hline 学位授与の要件 & 学 位 規則第 4 条第 1 項 該 当 \\
\hline 研究科・専攻 & 医学研究科脳統御医科学系専攻 \\
\hline 学位論文題目 & $\begin{array}{l}\text { Suppression of allergic inflammation by the prostaglandin E receptor } \\
\text { subtype EP3 } \\
\quad\left(\mathrm{PGE}_{2}-\mathrm{EP} 3 \text { 経路を介したアレルギー炎症抑制作用について) }\right.\end{array}$ \\
\hline
\end{tabular}

論文調査委員 教授坂口志文、教授湊長博教授宮地良樹

\section{論文内容の要旨}

プロスタノイドは生体内の種々の刺激に応じてアラキドン酸から生成される生理活性物質であり，アラキドン酸からシク ロオキシゲナーゼ $(\mathrm{COX})$ 及び各種合成酵素の働きにより $\mathrm{TXA}_{2}, \mathrm{PGF}_{2 \alpha}, \mathrm{PGE}_{2}, \mathrm{PGD}_{2}, \mathrm{PGI}_{2}$ が合成される。これまで， 当研究室では, $\mathrm{PGD}_{2}$ が DP 受容体を介してアレルギー喘息の発症に寄与していることを明らかにしており，現在では，肥 満細胞から放出される $\mathrm{PGD}_{2}$ がアレルギーの発症において重要な役割を果たしていることが広く認知されるまでになった。

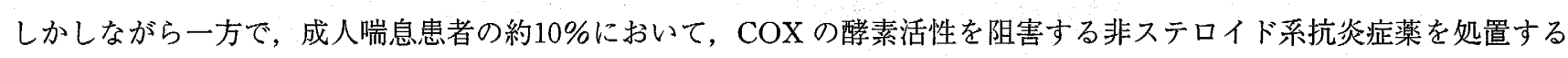
事により喘息発作が誘発されることが知られており，また，COX 欠損マウスにおいてもアレルギー喘息の元進が認められ ることが報告されている。この事は，プロスタノイドにはアレルギー促進性の $\mathrm{PGD}_{2}$ と，逆に抗アレルギー作用を有する その他のプロスタノイドが存在する事を示唆するものである。

$\mathrm{PGE}_{2}$ が肺において好酸球浸潤を抑制するという報告があることから，本研究では，喘息反応抑制性に働くプロスタノイ ドとして $\mathrm{PGE}_{2}$ に着目し，その効果についての解析を行った。

まず, 各 PGE 受容体欠損マウスを用いてアレルギー喘息モデルを作製し, 抗原最終吸入24時間後の気管支肺胞洗浄液中 の炎症性細胞数について検討を行ったところ, EP3 受容体欠損マウスにおいてのみ, 野生型と比較して有意な炎症性細胞 数の増加が認められた。また，野生型マウスに EP3作動薬を処置することにより，アレルギー喘息抑制効果が認められた。

次に, EP3の作用機序について検討を行うために, EP3 作動薬の投与タイミングを変えて比較検討を行った。その結果, EP3 作動薬を抗原チャレンジの30分前に投与した群において若干の抑制効果が認められ，一方， 3 時間後のみに投与した 群においては有意な喘息反応抑制効果が認められた。

即時型のアレルギー反応においては肥満細胞からのケミカルメディエーターの放出が重要な役割を担っているため, 抗原 感作肺を用いて実験を行ったところ, EP3 作動薬の処置により，肺組織からのケミカルメデイエーターの放出が有意に抑 制される事が明らかとなった。さらに，DNA microarrayを用いて遺伝子発現変化について検討を行ったところ，抗原吸入 により, TARCや eotaxin 等, 喘息との関連性が示唆されているケモカインの遺伝子発現の増加が認められ, この増加は EP3 作動薬処置群に扔いては有意に抑制されている事が明らかとなった。加えて, マウスの肺に扔けるEP3 受容体の発現 部位の同定を行った所，上記のケモカインの産生部位と同じく，気道上皮細胞においてその発現が認められた。

以上の結果をもとに, $\mathrm{PGE}_{2}-\mathrm{EP} 3$ 経路がアレルギー反応抑制性に働いている事を明らかにし，その作用機序として， $\mathrm{PGE}_{2}$ は肥満細胞および気道上皮細胞上の $\mathrm{EP} 3$ 受容体に作用し，肥満細胞からのケミカルメディエーターの放出挍よび気 道上皮細胞におけるケモカインの産生を抑制することによりアレルギー抑制効果を発揮するという機序について示唆した。

\section{論文審査の結果の要旨}

Suppression of allergic inflammation by the prostaglandin Ereceptor subtype EP3. 
（PGE $\mathrm{P}_{2}-\mathrm{EP} 3$ 経路を介したアレルギー炎症抑制作用について）

プロスタノイドはアラキドン酸からシクロオキシゲナーゼ（COX）を介して産生される生理活性物質の総称で各種プロ スタグランジン (PG) とトロンボキサンを含む。COX を阻害する非ステロイド系抗炎症薬 (NSAID) がー般にアレルギ 一を抑制しないことから，従来これら物質はアレルギーに関与しないとされていた。一方，最近， $\mathrm{PG} の 一 つ ， \mathrm{PGD}_{2}$ がア レルギーの伝達に働くことが見いだされ，NSAID が成人喘息患者の約10\%で発作を誘発することも知られている。これら の結果は, プロスタノイドにはアレルギー促進性と抑制性の両経路が存在する事を示唆すると考兄られる。本研究で, 申請 者は, 卵白アルブミン誘発喘息をモデルとして，PGE 受容体各サブタイプを欠損したマウスおよびこれらに特異的な作動 䒚を用い，抑制経路を検討した。その結果，EP3 受容体欠損マウスで野生型と比ベアレルギー炎症の有意なえ進を，EP3 作動薬投与で有意な抑制を認めた。また, EP3 作動薬が, 抗原感作肺からの伝達物質放出を阻害し, ケモカインなどアレ ルギー関連遺伝子の発現を抑制することを明らかにした。るらに，EP3 受容体がケモカイン産生の場である気道上皮に発 現すること, EP3 作動薬が抗原暴露 3 時間後に投与しても有効であることも明らかにした。これらの結果は, $\mathrm{PGE}_{2}-\mathrm{EP} 3$ 受容体がアレルギーのフィードバック抑制に働いていることを明らかとし，これを利用した EP3 作動薬のアレルギー治療 薬として可能性を示したものである。

以上の研究はアレルギー炎症での PG の役割の解明に貢献し, アレルギー学に奇与するところが多い。したがって本論文 は博士 (医学) の学位論文として価値のあるものと認める。

なお, 本学位授与申請者は, 平成17年 6 月 6 日実施の論文内容とそれに関連した諮問を受け, 合格と認められたものであ る。 